\title{
Eating behaviour of Indonesian adolescents: a systematic review of the literature
}

\author{
Cut Novianti Rachmi ${ }^{1}$, Hafizah Jusril ${ }^{1}$, Iwan Ariawan ${ }^{1,2}$, Ty Beal ${ }^{3,4}$ and \\ Aang Sutrisna ${ }^{5, *}$ \\ 'Reconstra Utama Integra, Jakarta, Indonesia: ${ }^{2}$ Faculty of Public Health, Universitas Indonesia, Depok, West Java, \\ Indonesia: ${ }^{3} \mathrm{Global}$ Alliance for Improved Nutrition (GAIN), Washington, DC, USA: ${ }^{4}$ Department of Environmental \\ Science and Policy, University of California, Davis, CA, USA: ${ }^{5}$ Global Alliance for Improved Nutrition (GAIN), Menara \\ Palma, 7th floor, Suite 705, Jl. HR Rasuna Said Blok X-2 Kav.6, Jakarta 12950, Indonesia
}

Submitted 3 September 2019: Final revision received 8 July 2020: Accepted 16 July 2020: First published online 10 September 2020

\begin{abstract}
Objectives: Global evidence has shown that behaviour acquired during adolescence often lasts into adulthood. Diet quality of and malnutrition in Indonesian adolescents is a neglected area of research. The current study reviews all studies related to eating behaviour in Indonesian adolescents to support evidence-based policy to improve diets.

Design: We searched electronic databases (six international and one local), from January 2000 to April 2018. The search terms used were (1) prevalence (prevalence OR number* OR case*, incidence OR survey), (2) adolescents (adolescen* OR school-age OR young adult), (3) Indonesia (Indonesia*) and (4) eating pattern (eat* OR fruit OR vegetable OR food recall OR food OR frequenc* OR consumption OR dietary intake). Articles were assessed against a critical appraisal tool.

Setting: Indonesia.

Participants: $10-19$ years.

Results: We discovered 15 studies related to eating behaviour, 5 of which were secondary analyses of nationally representative surveys and one was a nationwide survey. Of the nine studies, one study was conducted in multiple cities, and the rest were conducted in a single city or smaller area. There were seven main topics from the included studies: nutrient adequacy, fruit and vegetable consumption, water and beverage intake, $\mathrm{Na}$ intake, breakfast habit, snacking frequency and western fast food consumption.

Conclusions: Adolescents consume inadequate amounts of protein, fruits and vegetables, and excessive amounts of $\mathrm{Na}$ and western fast food. Measures are needed to improve and motivate adolescents to adopt healthier eating patterns. Furthermore, there is a need to have one standard definition and measurement of eating behaviour in Indonesia.
\end{abstract}

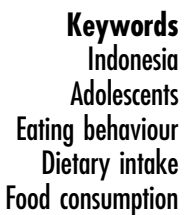

Adolescent malnutrition is a growing global concern. Behaviour acquired during adolescence often lasts into adulthood $^{(1)}$ and influences peers ${ }^{(2)}$. For some, health risks such as obesity and its psychological cost may also persist in adulthood ${ }^{(3)}$. Adolescents' nutritional status plays an essential role in the health of their offspring, particularly for girls ${ }^{(4,5)}$. Thus, adolescence is a critical period to instill positive dietary and health behaviours. Moreover, particularly, urban adolescents are relatively more adaptive to new changes compared with other age groups ${ }^{(6)}$. Hence, examining adolescent dietary patterns may reflect changes occurring in the community ${ }^{(2)}$, especially for those nations going through the double burden of malnutrition.

The double burden of malnutrition - a condition in which both under- and over-nutrition occurs - is widespread in many countries, especially in low- and middleincome countries $(\mathrm{LMIC})^{(7,8)}$. The fourth most populated

Disclaimer: This supplement received a publication grant from Global Alliance for Improved Nutrition (GAIN). 
nation globally, Indonesia, is still dealing with undernutrition while experiencing increasing overweight/obesity ${ }^{(9-12)}$. The Indonesia Basic Health Research (Riskesdas) survey reported that $25.7 \%$ of adolescents aged $13-15$ years were classified as stunted in 2018, a decrease from $35.1 \%$ in 2013 . Similarly, the proportion of thinness in adolescents $13-15$ years reduced from $14 \cdot 1 \%$ in 2013 to $8.7 \%$ in 2018 . Overweight or obesity increased from $10 \%$ in 2013 to $16 \%$ in 2018. A similar pattern is occurring in older age groups. Among individuals 16-18 years, the nationwide survey reported a decrease in stunting (31.2\% in 2013 to $26.9 \%$ in 2018) and thinness (19.4\% in 2013 to 8.1 in 2018). On the other end of the malnutrition spectrum, overweight or obesity increased from $7 \cdot 3 \%$ in 2013 to 13.5 in $2018^{(13-15)}$. A closer look is needed to support an evidence-based decision on this growing and transitioning nation. Previous pieces of evidence suggest that diets in Indonesia are becoming less healthy ${ }^{(11,16)}$. However, evidence on the adolescent group remains unexplored in Indonesia.

In Indonesia, the fact that adolescents will make up a growing proportion, demonstrating its significance, has led to more attention to this particular age group ${ }^{(17)}$. Nevertheless, there has been little implementation of programmes targeting adolescents; most programmes focus on adolescent girls, particularly on Fe and folic acid supplementation $^{(18)}$. Anecdotal evidence suggests that the lack of attention over the last decade has left a paucity of nutrition-related data on adolescents in Indonesia. Using evidence from other countries to inform local measures is not enough because of the vast differences between countries ${ }^{(2)}$. The call for more evidence on adolescent health has been made since a decade ago, yet not enough progress has been made ${ }^{(19)}$. This literature review aims to identify and synthesise all published studies on the dietary patterns in Indonesian adolescents. Such a review is crucial to inform policies and programmes for all levels of government in Indonesia and to identify research priorities.

\section{Methods}

\section{Inclusion and exclusion criteria}

The inclusion criteria were (a) studies that included people living in Indonesia aged $10-24$ years $^{(20)}$ as participants, (b) studies that investigated eating behaviour, (c) studies available in full text and (d) studies that were reported in English or in the Indonesian language published in journals (first and second authors speak Bahasa Indonesia and therefore are able to assess the quality and understand the results of these studies). We included studies of any design. The exclusion criteria were editorials or commentaries, studies only published as conference abstracts, those published only as reports or literature reviews and studies focusing on clinical features. Additional exclusion criteria are available in Fig. 1.

\section{Literature searching}

We performed electronic searches in several databases: Medline via OvidSP, Global Health via OvidSP, Embase via OvidSP, Health Collection via Informit Online, Web of Science and Scopus from January 2000 to April 2018. The search used the following terms: (1) prevalence (prevalence OR number* OR case*, incidence OR survey), (2) adolescents (adolescen* OR school-age OR young adult), (3) Indonesia (Indonesia*) and (4) eating pattern (eat* OR fruit OR vegetable OR food recall OR food OR frequenc* OR consumption OR dietary intake). The results were then combined from 1 to 4 with AND. The search in Indonesian databases used similar/translated terms. Articles written in the Indonesian language were searched through Indonesia National Institute of Health Research and Development portal which consists of twenty-two local health journals. We also traced included articles forwards on Google Scholar and performed a hand search of included article references to check for additional articles that may not have been identified during the systematic search. The search was run twice for clarity and doublechecked for quality.

\section{Document screening}

After collecting all articles identified from the search, we removed duplicates. Articles were screened against inclusion criteria; relevant full texts were retrieved for further assessment to ensure quality. Titles and abstracts were screened by two researchers. After final exclusion of articles according to our inclusion and exclusion criteria, relevant papers were ready for quality appraisal.

\section{Critical appraisal}

All full-text articles were screened against a tool by Loney et al. ${ }^{(21)}$. This tool appraised manuscripts based on three key indicators: validity of the study methods (six points), interpretation of results (one point) and applicability of results (one point). A complete table of the tool is available in online Supplementary Table 1 . We only included studies that had a score more than or equal to six points. Two authors conducted the critical appraisal, and the third author resolved any disagreements. To ensure the quality of our systematic review process, we refer to the PRISMA checklist to guide us in writing this review (prisma-statement.org).

\section{Synthesis of result and data extraction}

We present results in narrative synthesis, which allowed for an in-depth discussion of the qualitative heterogeneity between included studies. Results were further classified into studies conducted at the national-level, multi-city and single city or smaller area. We also classified results based on the topics discussed in the studies. 


\section{Results}

\section{Characteristics of studies}

Throughout this literature review, we used 10-24 years as the age group for adolescents as proposed by Sawyer et $a l .{ }^{(20)}$ on the search and screening process. However, most of the studies only included information on adolescents 10-19 years of age, fitting the WHO criteria. The complete process of screening is outlined in Fig. 1. Of the 15 included studies, one scored 8 , four scored 7 and ten scored 6. The result of our appraisal process is available in Table 1.

Six studies were conducted at the national level, only one was conducted in multiple cities in Indonesia and eight were conducted in one city or smaller in scale. Ten of these studies were conducted in schools and six were conducted in non-school settings. The earliest study was published in 2008 and the latest in 2017.

\section{Level of studies}

From six national studies available, two of them were conducted in several countries and four were conducted nationwide (secondary data analysis of nationally representative surveys). Two studies were non-school based and four school based. A more complete overview of these studies is available in Table 2 .

Table 2 shows that there was only one study available in the multi-cities level, a cross-sectional study conducted in five cities throughout Indonesia. The current study was conducted in non-school-going adolescents aged 10-19 years.

We discovered eight studies conducted in a single city or even smaller area, all of which surveyed school-going adolescents. Of these eight studies, five surveyed high school students and three junior high school students.

\section{Topics covered in the included studies}

Of the 15 included articles on eating behaviour/patterns among adolescents in Indonesia, we also divide them based on the topics covered in each study. The earliest study was published on 2008 and more published studies found by 2014 (Fig. 2). There were three studies on breakfast, three on food consumption (including fruit, vegetable, and meat consumption), one on western fast food consumption and one on snacking (Table 2). Some of these studies covered more than one sub-topic; thus, we have more than fifteen studies listed in Table 3.

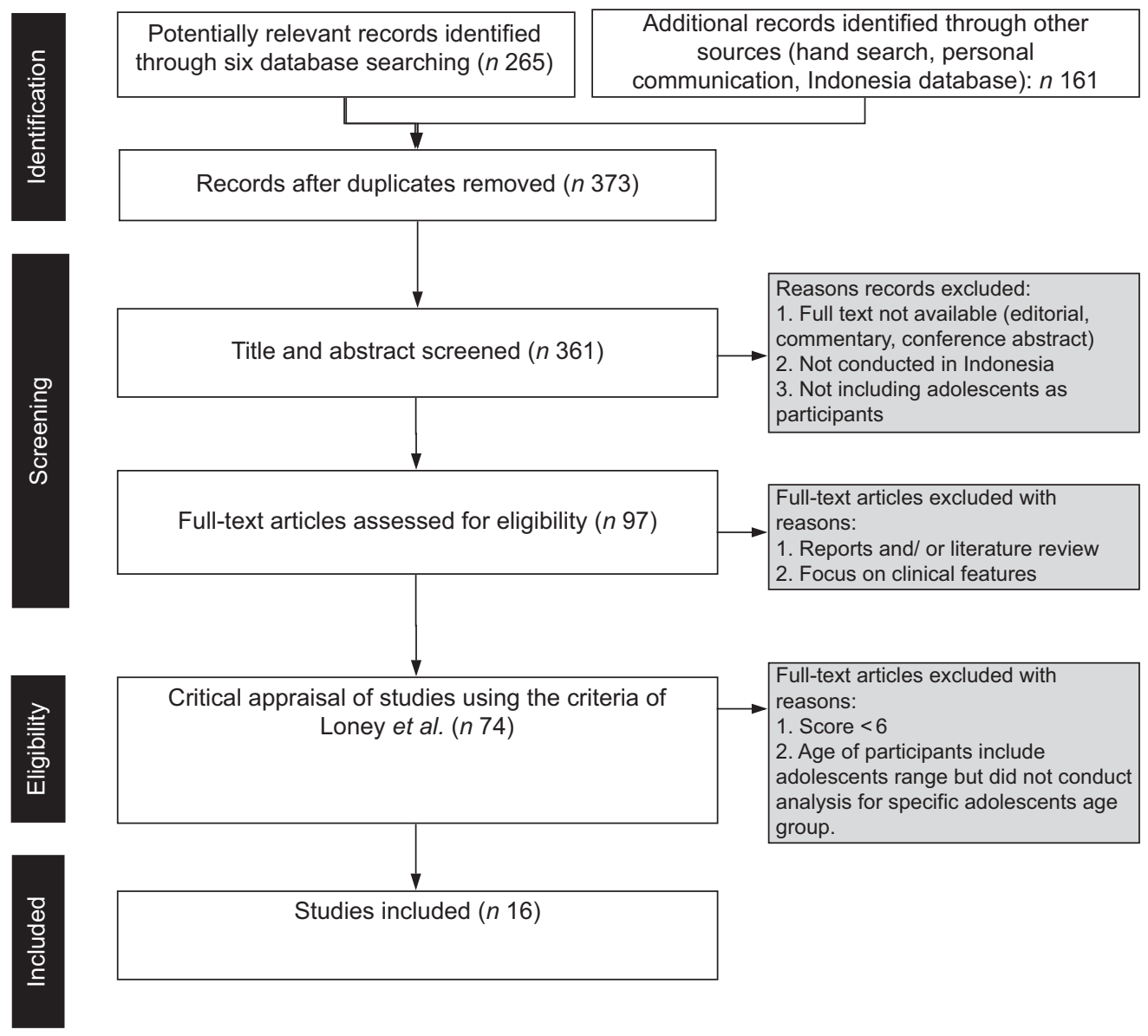

Fig. 1 A flow diagram showing the flow of citations reviewed in the current study 


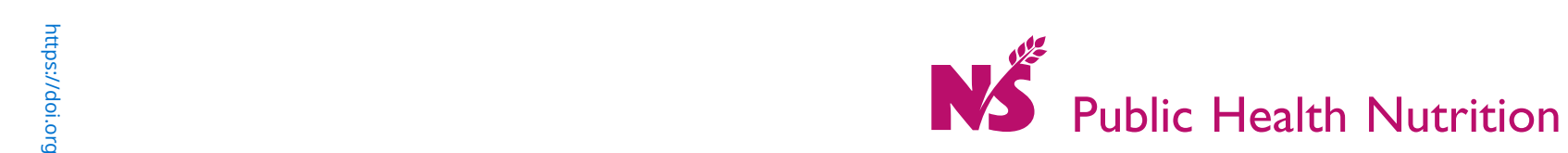

Table 1 Critical appraisal process using Loney et al.(21)

\begin{tabular}{|c|c|c|c|c|c|c|c|c|c|}
\hline Title of article (authors) & $\begin{array}{l}\text { Random } \\
\text { sample or } \\
\text { whole } \\
\text { population }\end{array}$ & $\begin{array}{l}\text { Unbiased } \\
\text { sampling } \\
\text { frame }\end{array}$ & $\begin{array}{l}\text { Adequate } \\
\text { sample } \\
\text { size } \\
(>300)\end{array}$ & $\begin{array}{l}\text { Measures } \\
\text { were the } \\
\text { standard }\end{array}$ & $\begin{array}{l}\text { Outcomes } \\
\text { measured in an } \\
\text { unbiased } \\
\text { fashion }\end{array}$ & $\begin{array}{l}\text { Adequate } \\
\text { response rate } \\
(70 \%) \text {, refusers } \\
\text { described }\end{array}$ & $\begin{array}{l}\mathrm{Cl} \text {, } \\
\text { subgroup } \\
\text { analysis }\end{array}$ & $\begin{array}{l}\text { Study } \\
\text { subjects } \\
\text { described }\end{array}$ & Score \\
\hline \multicolumn{10}{|l|}{ National } \\
\hline $\begin{array}{l}\text { Fruits and vegetables consumption and associated factors among } \\
\text { in-school adolescents in five Southeast Asian countries (Peltzer } \\
\text { and Pengpid }(24) \text { ) }\end{array}$ & $\mathrm{Y}$ & $\mathrm{Y}$ & $\mathrm{Y}$ & $\mathrm{Y}$ & $\mathrm{Y}$ & $\mathrm{Y}$ & $\mathrm{Y}$ & $\mathrm{Y}$ & 8 \\
\hline $\begin{array}{l}\text { Intake of water and beverages of children and adolescents in } \\
13 \text { countries (Guelinckx et al. }{ }^{(30)} \text { ) }\end{array}$ & $\mathrm{Y}$ & $\mathrm{Y}$ & $\mathrm{Y}$ & $\mathrm{Y}$ & $\mathrm{Y}$ & $\mathrm{Y}$ & $\mathrm{N}$ & $\mathrm{Y}$ & 7 \\
\hline $\begin{array}{l}\text { Consumption of fruits and vegetables in the context of balanced } \\
\text { nutrition among Indonesian: individual food consumption survey } \\
\text { analysis } 2014 \text { (Hermina and Prihatini }{ }^{(25)} \text { ) }\end{array}$ & $\mathrm{Y}$ & $\mathrm{Y}$ & $\mathrm{Y}$ & $\mathrm{Y}$ & $\mathrm{Y}$ & $\mathrm{Y}$ & $\mathrm{N}$ & $\mathrm{Y}$ & 7 \\
\hline $\begin{array}{l}\text { Food contribution in sodium intake of children at young age in } \\
\text { Indonesia (Prihatini et al. }{ }^{(31)} \text { ) }\end{array}$ & $\mathrm{Y}$ & $\mathrm{Y}$ & $\mathrm{Y}$ & $\mathrm{Y}$ & $\mathrm{Y}$ & $\mathrm{N} / \mathrm{A}$ & $\mathrm{N}$ & $\mathrm{Y}$ & 6 \\
\hline $\begin{array}{l}\text { Sodium intake among Indonesian population: analysis of Individual } \\
\text { Food Consumption Survey } 2014 \text { (Prihatini et al. }{ }^{\left({ }^{(2)}\right)} \text { ) }\end{array}$ & $\mathrm{Y}$ & $\mathrm{Y}$ & $\mathrm{Y}$ & $\mathrm{Y}$ & $\mathrm{Y}$ & $N / A$ & $\mathrm{Y}$ & $\mathrm{Y}$ & 7 \\
\hline $\begin{array}{l}\text { Indonesian food consumption against balanced nutrition value } \\
\left.\text { (Safitri et al. }{ }^{(23)}\right)\end{array}$ & $\mathrm{Y}$ & $\mathrm{Y}$ & $\mathrm{Y}$ & $\mathrm{Y}$ & $\mathrm{Y}$ & $\mathrm{N} / \mathrm{A}$ & $\mathrm{Y}$ & $\mathrm{Y}$ & 7 \\
\hline \multicolumn{10}{|l|}{ Multi-cities } \\
\hline $\begin{array}{l}\text { Knowledge, attitudes and adolescent behaviour on nutrition- } \\
\text { conscious families (Kadarzi): with special attention on weight } \\
\text { monitoring and consuming diverse foods (Sudirman and } \\
\text { Jahari( }{ }^{(2)} \text { ) }\end{array}$ & $\mathrm{Y}$ & $\mathrm{Y}$ & $\mathrm{Y}$ & $\mathrm{Y}$ & $\mathrm{Y}$ & $\mathrm{N} / \mathrm{A}$ & $\mathrm{N}$ & $\mathrm{Y}$ & 6 \\
\hline $\begin{array}{l}\text { Determinants of anemia in high school students in Jakarta } \\
\left.\text { (Ernawati and Saidin }{ }^{(27)}\right)\end{array}$ & $\mathrm{Y}$ & $\mathrm{Y}$ & $\mathrm{Y}$ & $\mathrm{Y}$ & $\mathrm{Y}$ & $\mathrm{N} / \mathrm{A}$ & $\mathrm{Y}$ & $\mathrm{Y}$ & 6 \\
\hline $\begin{array}{l}\text { Factors associated with fruits and vegetables consumption among } \\
\text { adolescent in } 4 \text { state high schools in West Jakarta (Bahria and } \\
\left.\text { Triyanti }{ }^{(28)}\right)\end{array}$ & $\mathrm{Y}$ & $\mathrm{Y}$ & $\mathrm{N}$ & Y & $\mathrm{Y}$ & $\mathrm{Y}$ & $\mathrm{N}$ & $\mathrm{Y}$ & 6 \\
\hline $\begin{array}{l}\text { Risk of western fast food consumption and skipping breakfast } \\
\text { against obesity: a study at SMAN } 1 \text { Cirebon (Banowati et al }{ }^{\left({ }^{(3)}\right)} \text { ) }\end{array}$ & $\mathrm{Y}$ & $\mathrm{N} / \mathrm{A}$ & $\mathrm{N}$ & $\mathrm{Y}$ & $\mathrm{Y}$ & $\mathrm{Y}$ & $\mathrm{Y}$ & $\mathrm{Y}$ & 6 \\
\hline $\begin{array}{l}\text { Relationship of breakfast habits and hydration status with } \\
\text { concentration of thinking in adolescents (Lentini and } \\
\text { Margawati }{ }^{\left({ }^{3}\right)} \text { ) }\end{array}$ & $\mathrm{Y}$ & $\mathrm{Y}$ & $\mathrm{N}$ & $\mathrm{Y}$ & $\mathrm{Y}$ & $\mathrm{N} / \mathrm{A}$ & $\mathrm{Y}$ & $Y$ & 6 \\
\hline $\begin{array}{l}\text { Breakfast habits, nutrition status, and quality of youth life of } \\
\text { Bosowa Junior High School Bina Insan Bogor (Niswah et al. }{ }^{(35)} \text { ) }\end{array}$ & $Y$ & $\mathrm{Y}$ & $\mathrm{N}$ & $\mathrm{Y}$ & $\mathrm{Y}$ & $\mathrm{Y}$ & $\mathrm{N}$ & $Y$ & 6 \\
\hline $\begin{array}{l}\text { Risk factors for breakfast and snack on overweight events in high } \\
\text { school adolescents (Agusanty et al. }{ }^{\left({ }^{\prime} 6\right)} \text { ) }\end{array}$ & $Y$ & $\mathrm{Y}$ & $\mathrm{N}$ & $Y$ & $\mathrm{Y}$ & $\mathrm{N} / \mathrm{A}$ & $\mathrm{Y}$ & $Y$ & 6 \\
\hline $\begin{array}{l}\text { Adolescents can prevent overweight with increasing self-efficacy } \\
\text { and vegetable-fruit consumption (Widianto et al. }{ }^{(29)} \text { ) }\end{array}$ & $Y$ & $\mathrm{Y}$ & $\mathrm{N}$ & $Y$ & $Y$ & $\mathrm{~N} / \mathrm{A}$ & $\mathrm{Y}$ & $Y$ & 6 \\
\hline $\begin{array}{l}\text { A social cognitive theory-based programme for eating patterns and } \\
\text { sedentary activity among overweight adolescents in Makassar, } \\
\text { South Sulawesi: a cluster randomised controlled trial (Hidayanty } \\
\text { et al. }{ }^{\left({ }^{3}\right)} \text { ) }\end{array}$ & Y & $\mathrm{Y}$ & $\mathrm{N}$ & $\mathrm{Y}$ & $\mathrm{Y}$ & $\mathrm{N} / \mathrm{A}$ & $\mathrm{Y}$ & $\mathrm{Y}$ & 6 \\
\hline
\end{tabular}

$\mathrm{Y}=\mathrm{Yes} ; \mathrm{N}=\mathrm{No} ; \mathrm{N} / \mathrm{A}=$ Information not available in the paper. 


\section{Nublic Health Nutrition}

Table 2 Studies included in the literature review based on level of studies

No. Title of article (authors)

National

Fruits and vegetables

consumption and associated

factors among in-school

adolescents in five Southeast

Asian countries (Peltzer and

Pengpid ${ }^{(24)}$ )

2 Intake of water and beverages of children and adolescents in 13 countries (Guelinckx et $a .^{(30)}$ )

3 Consumption of fruits and vegetables in the context of balanced nutrition among Indonesian: Individual Food Consumption Survey 2014 analysis (Hermina and Prihatini $^{(25)}$ )

$4 \quad$ Food contribution in sodium intake of children at young age (6-18 years) in Indonesia (Prihatini et al. ${ }^{(31)}$ )

5 Sodium intake among

Indonesian population:

analysis of Individual Food

Consumption Survey 2014 (Prihatini et al. ${ }^{(32)}$ )

6 Indonesian food consumption against balanced nutrition value (Safitri et al. ${ }^{(23)}$ )

Multi-cities

Knowledge, attitudes and

adolescent behaviour on

nutrition-conscious families

(Kadarzi): with special

attention on weight monitoring

and consuming diverse foods

(Sudirman and Jahari ${ }^{(22)}$ )
Time survey

conducted

Survey setting Subjects

Topic

Dietary pattern measures

Study design

Global School-Based

Health Survey in 5 South

2008

East Asian countries:

India, Indonesia,

Myanmar, Sri Lanka and

Thailand

13 countries: Latin America Between 2008

(Mexico, Brazil,

Argentina, Uruguay),

Europe (Spain, France,

Belgium, UK, Poland,

Turkey) and Asia (Iran,

China, Indonesia)

Nationwide (Studi

Konsumsi Makanan

Individu 2014)

and 2014, year

conducted in

Indonesia is

School based 13-15-yea

students

Fruits and

vegetables

Questionnaire consumption

Cross-sectional consumption

frequency in the past $30 \mathrm{~d}$

compared against

recommended at least two

daily servings of fruits and

three daily servings of

vegetables

School based Junior and Salty, sweet 7-d records on fluid intake, senior high food/sugary followed by face-to-face

Cross-sectional

interview

2014

school

drinks

Nationwide (Studi

Konsumsi Makanan

based

$6-18$ years

$\mathrm{Na}$ and salt

consumption

$24 \mathrm{~h}$ food recall, results

compared against

13-18 years, vegetable

Indonesia RDA (Pedoman

Gizi Seimbang)

Nationwide (Studi

Konsumsi Makanan

2014

Non-school

5-12 years

$\mathrm{Na}$ and salt

consumption

$24 \mathrm{~h}$ food recall, results

compared against

Indonesia recommended

2 grams $\mathrm{Na}$ intake per day

Nationwide (Studi

Konsumsi Makanan

2014

Non-school

$5-12$ years

Individu 2014)

based

13-18 years

Food diversity,

proportion

compad recall, results

compared against

Indonesia RDA (Pedoman

Gizi Seimbang)

West Java,

West Sumatera,

East Kalimantan,

West Nusa Tenggara

N/A

Non-school

10-19 years

Nutrition

education

Questionnaire, consume

protein, fruit and

and nutrients vegetables $\geq 5$ times/week

consumption 


\section{Nestic Health Nutrition}

Table 2 Continued

\begin{tabular}{|c|c|c|c|c|c|c|c|c|}
\hline No. & Title of article (authors) & Study site & $\begin{array}{l}\text { Time survey } \\
\text { conducted }\end{array}$ & Survey setting & Subjects & Topic & Dietary pattern measures & Study design \\
\hline & \multicolumn{8}{|l|}{ Single city or smaller area } \\
\hline 8 & $\begin{array}{l}\text { Determinants of anemia in high } \\
\text { school students in Jakarta } \\
\left.\text { (Ernawati and Saidin }{ }^{(27)}\right)\end{array}$ & Jakarta & 2005 & School based & $\begin{array}{l}\text { 15-19 years } \\
\text { senior high } \\
\text { school } \\
\text { students }\end{array}$ & $\begin{array}{l}\text { Fruits, } \\
\text { vegetables, } \\
\text { meats } \\
\text { consumption }\end{array}$ & $\begin{array}{l}\text { FFQ, consumption frequency } \\
\text { in the past week }\end{array}$ & Cross-sectional \\
\hline 9 & $\begin{array}{l}\text { Factors associated with fruits } \\
\text { and vegetables consumption } \\
\text { among adolescent in } 4 \text { public } \\
\text { high schools in West Jakarta } \\
\left.\text { (Bahria and Triyanti }{ }^{(28)}\right)\end{array}$ & West Jakarta & 2009 & School based & $\begin{array}{l}\text { Senior high } \\
\text { school } \\
\text { students }\end{array}$ & $\begin{array}{l}\text { Fruits and } \\
\text { vegetables } \\
\text { consumption }\end{array}$ & $\begin{array}{l}\text { Questionnaire, results } \\
\text { compared against } \\
\text { recommended twice a day } \\
\text { consumption in a week }\end{array}$ & Cross-sectional \\
\hline 10 & $\begin{array}{l}\text { Risk of western fast food } \\
\text { consumption and skipping } \\
\text { breakfast against obesity: a } \\
\text { study at SMAN } 1 \text { Cirebon } \\
\text { (Banowati et } \text { al. }^{(33)} \text { ) }\end{array}$ & Cirebon & 2010 & School based & $\begin{array}{l}\text { Senior high } \\
\text { school } \\
\text { students }\end{array}$ & $\begin{array}{l}\text { Fast-food } \\
\text { consumption }\end{array}$ & $\begin{array}{l}\text { FFQ, consumption frequency } \\
\text { in a month }\end{array}$ & $\begin{array}{l}\text { Case-control (obese- } \\
\text { non obese) }\end{array}$ \\
\hline 11 & $\begin{array}{l}\text { Relationship of breakfast habits } \\
\text { and hydration status with } \\
\text { concentration of thinking in } \\
\text { adolescents (Lentini and } \\
\left.\text { Margawati }{ }^{(34)}\right)\end{array}$ & Surakarta & 2014 & School based & $\begin{array}{l}\text { Senior high } \\
\text { school } \\
\text { students }\end{array}$ & Breakfast & $\begin{array}{l}\text { Questionnaire, breakfast } \\
\text { routinely }\end{array}$ & Cross-sectional \\
\hline 12 & $\begin{array}{l}\text { Breakfast habits, nutrition } \\
\text { status, and quality of youth } \\
\text { life of Bosowa Junior High } \\
\text { School Bina Insan Bogor } \\
\text { (Niswah et al. }{ }^{(35)} \text { ) }\end{array}$ & Bogor & 2014 & School based & $\begin{array}{l}\text { Junior high } \\
\text { school } \\
\text { students }\end{array}$ & Breakfast & $\begin{array}{l}24 \mathrm{~h} \text { food recall, breakfast } \\
\text { routinely }\end{array}$ & Cross-sectional \\
\hline 13 & $\begin{array}{l}\text { Risk factors for breakfast and } \\
\text { snack on overweight events } \\
\text { in high school adolescents } \\
\text { (Agusanty et al. }{ }^{(36)} \text { ) }\end{array}$ & Pontianak & 2013 & School based & $\begin{array}{l}\text { Senior high } \\
\text { school } \\
\text { students }\end{array}$ & $\begin{array}{l}\text { Breakfast and } \\
\text { snacking }\end{array}$ & $\begin{array}{l}\text { FFQ, breakfast routinely, } \\
\text { carbs on snack compared } \\
\text { against } \\
\text { recommended }<105.6 \mathrm{~g} \\
\text { for boys and } 89.4 \mathrm{~g} \text { for } \\
\text { girls }\end{array}$ & $\begin{array}{l}\text { Case-control } \\
\text { (overweight-normal } \\
\text { weight) }\end{array}$ \\
\hline 14 & $\begin{array}{l}\text { Adolescents can prevent } \\
\text { overweight with increasing } \\
\text { self-efficacy and vegetable- } \\
\text { fruit consumption (Widianto } \\
\text { et al. }{ }^{(29)} \text { ) }\end{array}$ & Jagakarsa & N/A & School based & $\begin{array}{l}\text { Grade } 7 \text { and } 8 \\
\text { junior high } \\
\text { school } \\
\text { students }\end{array}$ & $\begin{array}{l}\text { Fruits and } \\
\text { vegetables } \\
\text { consumption }\end{array}$ & $\begin{array}{l}\text { Questionnaire, results } \\
\text { compared against four } \\
\text { servings consumption per } \\
\text { day }\end{array}$ & Cross-sectional \\
\hline 15 & $\begin{array}{l}\text { A social cognitive theory-based } \\
\text { programme for eating } \\
\text { patterns and sedentary } \\
\text { activity among overweight } \\
\text { adolescents in Makassar, } \\
\text { South Sulawesi: a cluster } \\
\text { randomised controlled trial } \\
\left.\text { (Hidayanty et al. }{ }^{(37)}\right)\end{array}$ & Makassar & $\mathrm{N} / \mathrm{A}$ & School based & $\begin{array}{l}\text { 11-15 years } \\
\text { junior high } \\
\text { school } \\
\text { students }\end{array}$ & Snacking & FFQ, snacking frequency & Cross-sectional \\
\hline
\end{tabular}




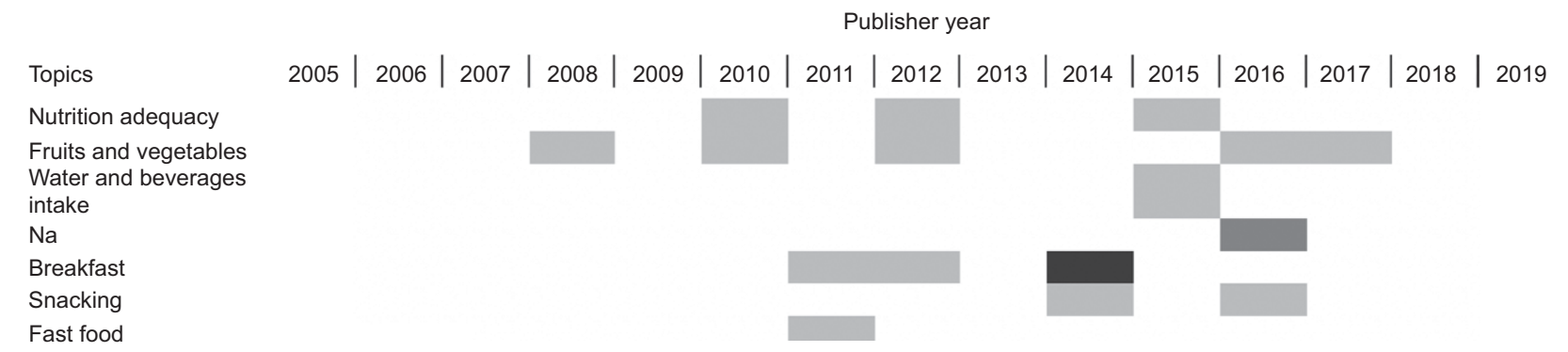

Fig. 2 Trends of topics in adolescents' eating behaviour explored on published papers. $\square$, one study; $\square$, two studies; $\mathbf{m}$, four studies

\section{Nutrient adequacy}

There were two studies addressing nutrient adequacy. One study was conducted in Integrated Health Posts (Posyandu) in six cities in Indonesia, involving more than 900 unmarried adolescents aged $10-19$ years ${ }^{(22)}$. The authors combined the consumption of animal-source protein and fruits and vegetables in one category. The other category was consumption of a multivitamin that included vitamin A. The results showed that only $18.8 \%$ of adolescents consumed animal-source protein, fruits and vegetables more than $5 \mathrm{~d}$ in a week, with the highest prevalence in South Sulawesi $(31.7 \%)$ and the lowest in East Nusa Tenggara (3.8\%). The national prevalence of adolescents consuming a multivitamin containing vitamin A was $9.6 \%$. Among the subnational level, the highest prevalence was found in East Nusa Tenggara province $(13.4 \%)$, and the lowest was in West Nusa Tenggara province $(6 \cdot 3 \%)^{(22)}$.

Another study analysed the nationwide Basic Health Survey and found notable inadequate consumption among adolescents (38.1\% among 6-12 year olds and 27.1\% among 13-19 year olds) ${ }^{(23)}$. Most adolescents already consumed $\geq 4$ food groups ( $81 \cdot 1 \%$ among $6-12$ year olds and $83.9 \%$ among 13-19 year olds). However, only a few, 23.5 and $24.9 \%$ of those aged 6-12 and $13-19$ years, respectively, consumed an appropriate proportion of carbohydrate, protein and fat (60:15:25).

\section{Fruit and vegetable consumption}

There were five studies that addressed fruit and vegetable consumption. A secondary data analysis using the Global School-based Health Surveys 2008 dataset was conducted by Peltzer and Pengpid in five Southeast Asian countries, including Indonesia ${ }^{(24)}$. The study in Indonesia involved more than 2800 participants aged $13-15$ years. The current study revealed that $75.2 \%$ of adolescents in Indonesia consumed fruits and vegetables less than five servings per day in the past $30 \mathrm{~d}$. They also analysed food insecurity, defined as going hungry due to lack of food at home in the past $30 \mathrm{~d}$, and categorised the response to never, rarely, sometimes, most of the times and always. Results showed that $5.8 \%$ of adolescents responded 'most of the times' or 'always went hungry' in the past $30 \mathrm{~d}^{(24)}$.

The next study was a secondary data analysis of Individual Food Consumption Survey (SKMI) in Indonesia ${ }^{(25)}$. The current study involved more than 15000 adolescents aged 13-18 years. They used the recommended intake according to the Balanced Nutrition Guidelines (Pedoman Gizi Seimbang) $)^{(26)}$ which state the minimally adequate fruit and vegetable consumption is $400 \mathrm{~g} / \mathrm{d}$ (250 g vegetables and $150 \mathrm{~g}$ fruits). Indonesia's Balanced Nutrition Guidelines refer to the WHO guidelines for fruit and vegetable intake. The consumption under this cut-off was considered inadequate. In this age group, 94.7 and $28.9 \%$ stated they consumed vegetables and fruits, respectively, each day. However, the amount of vegetables and fruits consumed was 62.1 and $106.6 \mathrm{~g}$, respectively. An estimated $98.4 \%$ of adolescents aged 13-18 years was considered to have inadequate intake of fruits and vegetables ${ }^{(25)}$.

Another included study performed secondary data analysis on the Survey of School-Children Nutritional Status in Indonesia ${ }^{(27)}$. From ten available cities in the survey, the authors focused in Jakarta city. The analysis included 491 students aged 15-19 years and asked about the frequency of fruit and vegetable consumption in the past week (never, sometimes or every day). The frequencies of vegetable consumption in the past week were $6 \cdot 3$, 54.4 and $39.3 \%$, respectively. The frequencies of fruit consumption in the past week were $7 \cdot 3,69.5$ and $23.2 \%$, respectively. Among those who consumed fruits and vegetables, most consumed them sometimes rather than never or every day ${ }^{(27)}$.

Another study involved 214 students from four high schools in West Jakarta ${ }^{(28)}$. The current study measured consumption of fruits and vegetables in the past week and categorised consumption as adequate if the students consumed two servings per day (fourteen servings/week) of each item. Only 7.9 and $22.9 \%$ of students consumed adequate fruits and vegetables in the last week, respectively. Factors that affected these prevalences were the amount of pocket money (associated with fruit consumption) and whether students liked vegetables (associated with vegetable consumption) ${ }^{(28)}$. Widianto et al. conducted a study of 156 students in grades seven and eight from junior high schools in Jagakarsa ${ }^{(29)}$. They considered adequate consumption of fruits and vegetables as consumption of four or more servings per day. The results showed that $76.3 \%$ of these students had inadequate consumption of fruits and vegetables ${ }^{(29)}$. 
Table 3 List of studies around eating behaviour/patterns among adolescents conducted in Indonesian adolescents based on topics

\begin{tabular}{|c|c|c|c|c|}
\hline Level of study & Topic & Authors & Results & \\
\hline \multicolumn{5}{|c|}{ Nutrients adequacy } \\
\hline National & $\begin{array}{l}\text { Indonesian food } \\
\text { consumption against } \\
\text { balanced nutrition } \\
\text { value }^{(46)}\end{array}$ & Safitri et al. & $\begin{array}{l}\text { Consume } \geq 4 \text { food groups } \\
6-12 \text { years: } 81 \cdot 1 \% \\
13-19 \text { years: } 83 \cdot 9 \% \\
\text { Adequate consumption }(80-120 \% \\
\text { AKG): } \\
6-12 \text { years: } 38 \cdot 1 \% \\
13-19 \text { years: } 27 \cdot 1 \%\end{array}$ & $\begin{array}{l}\text { Good proportion of carbohydrate, } \\
\text { protein, fat consumption } \\
\text { (60:15:25): } \\
\text { 6-12 years: } 23.5 \% \\
\text { 13-19 years: } 24.9 \%\end{array}$ \\
\hline Multi-cities & $\begin{array}{l}\text { Knowledge, attitudes and } \\
\text { adolescent behaviour on } \\
\text { nutrition-conscious } \\
\text { families (Kadarzi): with } \\
\text { special attention on } \\
\text { weight monitoring and } \\
\text { consuming diverse } \\
\text { foods }\end{array}$ & $\begin{array}{l}\text { Sudiman and } \\
\text { Jahari }\end{array}$ & $\begin{array}{l}10-19 \text { years; consume protein, fruit } \\
\text { and vegetables } \geq 5 \text { times/week: } \\
18.8 \%\end{array}$ & $\begin{array}{l}\text { 10-19 years; consume } \\
\text { multivitamin containing vitamin } \\
\text { A: } 9.6 \%\end{array}$ \\
\hline \multicolumn{5}{|c|}{ Fruits and vegetables } \\
\hline National & $\begin{array}{l}\text { Fruits and vegetables } \\
\text { consumption and } \\
\text { associated factors } \\
\text { among in-school } \\
\text { adolescents in five } \\
\text { Southeast Asian } \\
\text { countries }^{(24)}\end{array}$ & $\begin{array}{l}\text { Peltzer and } \\
\text { Pengpid }\end{array}$ & $\begin{array}{l}13-15 \text { years } \\
\text { Fruits and vegetables }<5 \text { servings/ } \\
\text { d: } 75 \cdot 2 \%\end{array}$ & $\begin{array}{l}13-15 \text { years } \\
\text { Most of the times or always went } \\
\text { hungry: } 5.8 \%\end{array}$ \\
\hline National & $\begin{array}{l}\text { Consumption of fruits and } \\
\text { vegetables in the } \\
\text { context of balanced } \\
\text { nutrition among } \\
\text { Indonesian: Individual } \\
\text { Food Consumption } \\
\text { Survey Analysis } 2014^{(25)}\end{array}$ & $\begin{array}{l}\text { Hermina and } \\
\text { Prihatini }\end{array}$ & $\begin{array}{l}\text { Inadequate consumption of fruit and } \\
\text { vegetables; } \\
13-18 \text { years: } 98.4 \%\end{array}$ & \\
\hline Single city & $\begin{array}{l}\text { Determinants of anemia in } \\
\text { high school students in } \\
\text { Jakarta }^{(27)}\end{array}$ & $\begin{array}{l}\text { Ernawati and } \\
\text { Saidin }\end{array}$ & $\begin{array}{l}15-19 \text { years, vegetables } \\
\text { consumption in the past week } \\
\text { Never: } 6.3 \% \\
\text { Sometimes: } 54.4 \%\end{array}$ & $\begin{array}{l}15-19 \text { years, fruits consumption } \\
\text { in the past week } \\
\text { Never: } 7.3 \% \\
\text { Sometimes: } 69.5 \%\end{array}$ \\
\hline Single city & $\begin{array}{l}\text { Factors associated with } \\
\text { fruits and vegetables } \\
\text { consumption among } \\
\text { adolescent in } 4 \text { state } \\
\text { high schools in West } \\
\text { Jakarta }\end{array}$ & $\begin{array}{l}\text { Bahria and } \\
\text { Triyanti }\end{array}$ & Consume fruits <2 times/d: $92.1 \%$ & $\begin{array}{l}\text { Consume vegetables }<2 \text { times } / \mathrm{d} \text { : } \\
77.1 \%\end{array}$ \\
\hline Single city & $\begin{array}{l}\text { Adolescents can prevent } \\
\text { overweight with } \\
\text { increasing self-efficacy } \\
\text { and vegetable-fruit } \\
\text { consumption } \\
\text { (29) }\end{array}$ & Widianto et al. & $\begin{array}{l}\text { Fruits and vegetables } \\
\text { consumption }<4 \text { servings/d: } \\
76.3 \%\end{array}$ & \\
\hline \multicolumn{5}{|c|}{ Water and beverages intake } \\
\hline National & $\begin{array}{l}\text { Intake of water and } \\
\text { beverages of children } \\
\text { and adolescents in } 13 \\
\text { countries }^{(30)}\end{array}$ & Guelinckx et al. & $\begin{array}{l}\text { 10-17 years, mean ml/d (SD) } \\
\text { Water: } \\
\text { Male: } 1621(872) \\
\text { Female: } 1589(812) \\
\text { 10-17 years, mean } \mathrm{ml} / \mathrm{d}(\mathrm{SD}) \\
\text { Hot beverages: } \\
\text { Male: } 129(224) \\
\text { Female: } 101(168) \\
\text { 10-17 years, mean } \mathrm{ml} / \mathrm{d}(\mathrm{SD}) \\
\text { Regular soft beverages: } \\
\text { Male: } 200(334) \\
\text { Female: } 203(389)\end{array}$ & $\begin{array}{l}\text { 10-17 years, mean ml/d (SD) } \\
\text { Milk: } \\
\text { Male: } 73(140) \\
\text { Female: } 74(166) \\
\text { 10-17 years, mean ml/d (SD) } \\
\text { Juices: } \\
\text { Male: } 13(41) \\
\text { Female: } 27(87)\end{array}$ \\
\hline \multicolumn{5}{|c|}{ 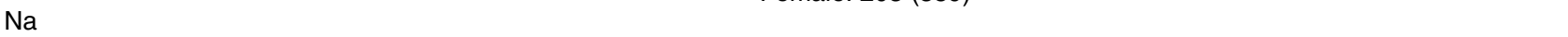 } \\
\hline National & $\begin{array}{l}\text { Food contribution in } \\
\text { sodium intake of } \\
\text { children at young age } \\
\text { (6-18 years) in } \\
\text { Indonesia( }{ }^{(31)}\end{array}$ & Prihatini et al. & $\begin{array}{l}6-18 \text { years, > } 2000 \mathrm{mg} / \mathrm{d}: \\
\text { Male: } 55 \cdot 3 \% \\
\text { Female: } 54 \cdot 2 \% \\
\text { Total: } 55 \cdot 3 \%\end{array}$ & $\begin{array}{l}6-18 \text { years, Na source: } \\
\text { Salt: } 43.9 \% \\
\text { Food: } 56 \cdot 1 \%\end{array}$ \\
\hline
\end{tabular}


Table 3 Continued

\begin{tabular}{|c|c|c|c|c|}
\hline Level of study & Topic & Authors & Results & \\
\hline National & $\begin{array}{l}\text { Sodium intake among } \\
\text { Indonesian population: } \\
\text { analysis of Individual } \\
\text { Food Consumption } \\
\text { Survey } 2014^{(32)}\end{array}$ & Prihatini et al. & $\begin{array}{l}5-12 \text { years, } \geq 2000 \mathrm{mg} / \mathrm{d}: 55 \cdot 2 \% \\
13-18 \text { years, } \geq 2000 \mathrm{mg} / \mathrm{d}: 55 \cdot 7 \%\end{array}$ & $\begin{array}{l}\text { 5-12 years, Na source: } \\
\text { Salt: } 43 \cdot 3 \% \\
\text { Food: } 56 \cdot 7 \% \\
\text { 13-18 years, Na source: } \\
\text { Salt: } 44 \cdot 1 \% \\
\text { Food: } 55 \cdot 9 \%\end{array}$ \\
\hline \multicolumn{5}{|l|}{ Breakfast } \\
\hline Multi-cities & $\begin{array}{l}\text { Knowledge, attitudes and } \\
\text { adolescent behaviour on } \\
\text { nutrition-conscious } \\
\text { families (Kadarzi): with } \\
\text { special attention on } \\
\text { weight monitoring and } \\
\text { consuming diverse } \\
\text { foods }\end{array}$ & $\begin{array}{l}\text { Sudiman and } \\
\text { Jahari }\end{array}$ & 10-19 years, breakfast: $88.6 \%$ & \\
\hline Single city & $\begin{array}{l}\text { Risk of western fast food } \\
\text { consumption and } \\
\text { skipping breakfast } \\
\text { against obesity: a study } \\
\text { at SMAN } 1 \text { Cirebon }{ }^{(33)}\end{array}$ & Banowati et al. & $\begin{array}{l}\text { Breakfast } \\
\text { Obese: } 78.9 \% \text { Non-obese: } 94.7 \%\end{array}$ & \\
\hline Single city & $\begin{array}{l}\text { Relationship of breakfast } \\
\text { habits and hydration } \\
\text { status with concentration } \\
\text { of thinking in } \\
\text { adolescents } \\
(34)\end{array}$ & $\begin{array}{l}\text { Lentini and } \\
\text { Margawati }\end{array}$ & 15-19 years, breakfast: $52.5 \%$ & \\
\hline Single city & $\begin{array}{l}\text { Breakfast habits, nutrition } \\
\text { status, and quality of } \\
\text { youth life of Bosowa } \\
\text { Junior High School Bina } \\
\text { Insan Bogor }{ }^{(35)}\end{array}$ & Niswah et al. & $13-15$ years, breakfast: $83.3 \%$ & \\
\hline Single city & $\begin{array}{l}\text { Risk factors for breakfast } \\
\text { and snack on } \\
\text { overweight events in } \\
\text { high school } \\
\text { adolescents }^{(36)}\end{array}$ & Agusanty et al. & $\begin{array}{l}\text { Breakfast } \\
\text { Overweight: } 11 \% \\
\text { Non-overweight: } 28 \%\end{array}$ & $\begin{array}{l}\text { Routine high-carb breakfast } \\
\text { Overweight: } 36.4 \% \\
\text { Non-overweight: } 7.1 \% \\
\text { (OR } 7.5 ; P=0.04 \text { ) }\end{array}$ \\
\hline \multicolumn{5}{|l|}{ Snacking } \\
\hline Single city & $\begin{array}{l}\text { Risk factors for breakfast } \\
\text { and snack on } \\
\text { overweight events in } \\
\text { high school } \\
\text { adolescents }^{(36)}\end{array}$ & Agusanty et al. & $\begin{array}{l}\text { Snacking }>2 \text { times/d } \\
\text { Overweight: } 62 \% \\
\text { Non-overweight: } 46 \% \\
\text { (OR=1.9; } P=0.023 \text { ) } \\
\text { High-carb snacking } \\
\text { Overweight: } 31 \% \\
\text { Non-overweight: } 9 \% \\
(\text { OR }=4.5 ; P=0.0001)\end{array}$ & $\begin{array}{l}\text { High energy snacking } \\
\text { Overweight: } 44 \% \\
\text { Non-overweight: } 27 \% \\
(\mathrm{OR}=2 \cdot 1 ; P=0.012)\end{array}$ \\
\hline Single city & $\begin{array}{l}\text { A social cognitive theory- } \\
\text { based programme for } \\
\text { eating patterns and } \\
\text { sedentary activity among } \\
\text { overweight adolescents } \\
\text { in Makassar, South } \\
\text { Sulawesi: a cluster } \\
\text { randomised controlled } \\
\text { trial }^{(37)}\end{array}$ & Hidayanty et al. & $\begin{array}{l}11-15 \mathrm{y}, \text { median of snacking habit } \\
\text { frequency score } \\
0.50(0 \cdot 27 \pm 0 \cdot 99)(3-6 \text { times/week })\end{array}$ & \\
\hline \multicolumn{5}{|c|}{ Western fast food } \\
\hline Single city & $\begin{array}{l}\text { Risk of western fast food } \\
\text { consumption and } \\
\text { skipping breakfast } \\
\text { against obesity: a study } \\
\text { at SMAN } 1 \text { Cirebon }{ }^{(33)}\end{array}$ & Banowati et al. & $\begin{array}{l}\text { Frequency of western fast food } \\
\text { consumption/month } \\
\text { Obese: } 27 \cdot 9 \pm 20 \cdot 8 \\
\text { Non-obese } 20 \cdot 8 \pm 16 \cdot 9 \\
\text { Energy contribution from western } \\
\text { fast food consumption ( } \% \text { total } \\
\text { kcal/d†) } \\
\text { Obese: } 8 \cdot 4 \pm 5 \cdot 2 \\
\text { Non-obese: } 6 \cdot 2 \pm 5 \cdot 1\end{array}$ & $\begin{array}{l}\text { Energy intake of western fast } \\
\text { food consumption (kcal/d }+ \text { ) } \\
\text { Obese: } 263 \pm 184 \\
\text { Non-obese: } 140 \pm 126\end{array}$ \\
\hline
\end{tabular}

†To covert kcal to kJ multiply it by $4 \cdot 184$. 


\section{Water and beverages intake}

There is only one study of water and beverage intake in adolescents, and it was conducted in thirteen countries, including Indonesia ${ }^{(30)}$. The current study included 595 adolescents aged 10-17 years. The results showed that in both male and female adolescents, the most consumed beverage is water (regular and tap), followed by regular soft beverages (sugared and artificially sweetened, carbonated and non-carbonated soft drinks, energy drinks, sports drinks, other sugared or artificially sweetened soft drinks), hot beverages (coffee, tea and other hot beverages), milk (and milk derivatives) and juices ${ }^{(30)}$.

\section{Sodium intake and source}

A secondary data analysis of Individual Food Consumption Survey (SKMI) in Indonesia was conducted by Prihatini et $a l^{(31)}$. The results revealed that in adolescents aged 13-18 years, $44.3 \%$ of $\mathrm{Na}$ intake was consumed from salt and $55.7 \%$ from other food ingredients. In all age groups (6-18 years), $55 \cdot 3 \%$ of participants consumed more than $2 \mathrm{~g} / \mathrm{d}$ of $\mathrm{Na}$. Another secondary analysis of Individual Food Consumption Survey (SKMI) reported similar results: 55.2 and $55.7 \%$ of the population aged 5-12 and 13-18 years, respectively, consumed $\geq 2 \mathrm{~g}$ of $\mathrm{Na}$ per $\mathrm{d}$. Of all populations ( 0 to $>55$ years), individuals aged 13-18 and $19-55$ years consumed the most $\mathrm{Na}$, that is, $2 \cdot 8 \mathrm{~g} / \mathrm{d}^{(32)}$.

\section{Breakfast habit}

We found five studies addressing breakfast habits of adolescents. The first study, conducted by Sudiman and Jahari in Integrated Health Posts (Posyandu) in six cities in Indonesia, revealed that as many as $88.6 \%$ of adolescents aged 10-19 years have breakfast regularly. The highest prevalence was found in West Nusa Tenggara (92.3\%) followed by East Kalimantan (90.5\%), East Nusa Tenggara (89.2\%), West Java (88.3\%), South Sulawesi (87.7\%) and West Sumatera $(84.6 \%)^{(22)}$. Banowati et al. conducted a case-control study involving seventy-six senior high school students, thirty-eight of whom were classified as obese and categorised to the case group ${ }^{(33)}$. They found that $78.9 \%$ of obese students and a higher percentage of those who were not obese $(94.7 \%)$ had breakfast in the morning. There was also a significant difference $(P=0.019)$ between the frequency that obese students had breakfast compared with their non-obese counterparts ( 4.5 times/week $v .5 .8$ times/week, respectively) ${ }^{(33)}$.

Another study on breakfast habits was performed by Lentini and Margawati, where they randomly sampled eighty female high school students aged 15-19 years in Surakarta. They found that $47.5 \%$ of these students were not used to having breakfast in the morning ${ }^{(34)}$. The next study was also conducted in school, targeting junior high school students aged 13-15 years in Bogor ${ }^{(35)}$. The author found that $16.7 \%$ of students were not used to having breakfast in the morning. Although the number of students who were used to having breakfast was much higher
(83.3\%), there was no significant difference in nutritional status between the two groups ${ }^{(35)}$. The last study that observed breakfast habits was also a case-control study, involving 200 students (100 overweight students as case group $)^{(36)}$. A higher prevalence of students who routinely had breakfast was found among those who were not overweight $(28 \%)$ compared with their overweight counterparts (11\%).

\section{Snacking frequencies}

A study by Agusanty et al. highlighted a significant difference $(P=0.023)$ in the frequency of snacking more than two times per day between those who were overweight (62\%) and those who were not overweight (46\%). Overweight adolescents were also twice more likely to consume higher energy content snack (OR 2.1; $P=0 \cdot 012$ ) and fourth times more likely to consume high-carb snacks (OR 4.5; $P=0.0001$ ). Instant noodles, vegetable deep fired $\mathrm{f}$ itters (bakwan) and candies were the top three most frequently consumed snacks in both groups. Overweight adolescents also frequently snack on fried rice and chocolate, meanwhile non-overweight group opted for banana fritters and tofu fritters ${ }^{(36)}$. Another study observed the snacking habits of 172 students from eight schools in Makassar and found that students snacked 3-6 times/week ${ }^{(37)}$.

\section{Western fast food consumption}

The study by Banowati et al. ${ }^{(33)}$ highlighted the difference between the frequency of consuming western fast food between obese (27.9 times/month) and non-obese (20.8 times/month) students, although the difference was not significant $(P=0 \cdot 180)$. We found a significant difference $(P=0.001)$ in the energy intake from western fast food consumption: $1100.4 \pm 769.9 \mathrm{~kJ} / \mathrm{d}(263 \pm 184 \mathrm{kcal} / \mathrm{d})$ for the obese group and $585.8 \pm 527.2 \mathrm{~kJ} / \mathrm{d}(140 \pm 126 \mathrm{kcal} / \mathrm{d})$ for their non-obese counterpart. Samples of western fast food include pizza, fried chicken, french fries and a doughnut.

\section{Discussion}

Our literature review revealed fifteen studies about eating behaviour among Indonesian adolescents. Of these, six were conducted nationwide, one in multiple cities and eight in a single city or smaller area. Each study used different definitions and/or measurements of eating pattern variables; thus, statistical comparisons between studies were challenging. We categorised the topics discussed in the included studies into seven main topics: nutrient adequacy, fruit and vegetable consumption, water and beverage intake, $\mathrm{Na}$ intake, breakfast habits, snacking frequencies and western fast food consumption.

Evidence suggests overall eating habits of Indonesian adolescents need improvement. About $18 \%$ of sampled adolescents in six cities consumed animal-source protein, fruits and vegetables less than $5 \mathrm{~d} /$ week $^{(22)}$. This finding, however, needs to be interpreted carefully, as only animal-source 
protein was included, while the Indonesian national guidelines suggest consuming 2-4 portions of plant-source or animal-source protein daily ${ }^{(26)}$. All studies revealed inadequate fruit and vegetable consumption, in either serving size and/or frequencies ${ }^{(24,25,27-29)}$. A secondary analysis of a nationally representative survey recorded $98.4 \%$ adolescents aged 13-18 years consumed inadequate fruits and vegetables $(<400 \mathrm{~g} / \mathrm{d})^{(25)}$. These findings suggest attention is needed on diet quality in addition to energy adequacy among adolescents.

A systematic review of diets among adolescent girls in LMIC reported only half of adolescents consumed vegetables and fewer (37\%) consumed them daily, despite a high variation between regions. The highest proportion of daily vegetable consumption was recorded among Middle East and North African adolescent girls (82\%) followed by South Asia (72\%), Africa (5\%) and Latin America and the Caribbean (1\%). About $73 \%$ of adolescent girls living in East Asia and the Pacific did not meet the recommended two servings of fruit per day and about $48 \%$ of girls consumed less than three servings of vegetables per day ${ }^{(38)}$. Adolescent girls living in urban and peri-urban areas consumed more energy per day than girls from urban slums or rural areas. This pattern may indicate an epidemiologic pattern of nutrition transition that is affecting nations across the globe ${ }^{(38)}$. Unfortunately, our limited sample impedes observations on age and residential differences. However, our findings on energy and fruit and vegetable inadequacy suggest changes in adolescent eating behaviours and/or food patterns contribute to the increasing double burden of malnutrition in Indonesia ${ }^{(9)}$.

Previous evidence in Indonesia indicates shifting consumption towards energy-dense foods and/or beverages among Indonesians ${ }^{(39)}$, while dietary guidelines are generally unmet ${ }^{(40)}$. We found more than half of children and adolescents 6-18 years consumed more $\mathrm{Na}$ than the daily recommended amount, and $50 \%$ of the consumption was sourced from food ${ }^{(31)}$. Concern for high $\mathrm{Na}$ intake stems from its association with $\mathrm{CVD}^{(41)}$ and its contribution to death from $\mathrm{CVD}^{(42)}$. Although we do not find local evidence of association between high $\mathrm{Na}$ intake and mortality, studies in Indonesia have found an association between high $\mathrm{Na}$ intake and elevated blood pressure, a recognised risk factor of $\mathrm{CVD}^{(43,44)}$. A prospective cohort study in Bogor, Indonesia found that adults who consumed more than or equal to $2 \mathrm{~g} / \mathrm{d}$ of $\mathrm{Na}$ had higher incidences of hypertension compared with those consuming $<2 \mathrm{~g} / \mathrm{d}^{(44)}$. The combination of diets high in $\mathrm{Na}$ and low in $\mathrm{K}-$ which is highest in fruits and vegetables - puts adolescents at particularly high risk of high-blood pressure and associated CVD later in life ${ }^{(45)}$. Further, a study in our review reported that sugary beverages were the second most commonly consumed beverages after water among 10-17 year olds, and females recorded higher consumption than males ${ }^{(30)}$. This finding is aligned with evidence in other LMIC where energy-dense foods, including sweet and salty items, are widely consumed. Half of adolescent girls (51\%) in LMIC consume sugar-sweetened beverages. Of girls who consumed them, half (49\%) consumed them 4-6 times/week and 46\% consumed them 2-3 times/week ${ }^{(38)}$. Our findings suggest adolescent diets in Indonesia need to be shifted from energy-dense, nutrient-poor processed foods to nutrientrich, minimally processed foods. More research is needed to determine how to accomplish this, especially since geographical and cultural aspects are highly variable in Indonesia, and different approaches may be necessary depending on the local context.

Additionally, our review found that skipping breakfast $^{(22,33-36)}$ and snacking were common among Indonesian adolescents $^{(36,37)}$, which is typical for adolescents in LMIC $^{(38)}$. Included studies observed consistent patterns that overweight/obese adolescents tend to skip breakfast and snack more than their normal-weight counterparts ${ }^{(33,36)}$. This is similar to findings from a meta-analysis which reported a positive association of skipping breakfast with the prevalence of overweight or obesity in Asia and Pacific regions ${ }^{(46)}$. Snacking is also associated with skipping breakfast among adolescents: females and adolescents living in metropolitan areas skipped breakfast more than those living in rural areas ${ }^{(47)}$. While studies showing association do not demonstrate that skipping breakfast or snacking causes overeating or overweight and obesity, there is a plausible mechanism that may explain a causal relationship. Adolescents that skip breakfast may be more likely to consume unhealthy foods that facilitate overeating when snacking, due to the context in which they snack. For example, they may have junk food or processed foods at school instead of a home-cooked meal or fresh fruits and vegetables. The impact of snacking on overweight and obesity may have to do primarily with the quality of the snack. A snack containing an egg and fresh fruits and vegetables contains a much higher nutrient density, fibre and protein content as well as lower energy density than most common snack foods and is unlikely to facilitate overeating. Foods available in adolescent environments, such as schools, are a gap that needs to be explored. More research is needed to understand how to implement effective dietary interventions targeted to adolescents that reduce all forms of malnutrition, including undernutrition, overweight/ obesity and related noncommunicable diseases.

Our findings highlight the poor diet quality of Indonesian adolescents, reflecting an urgent need for effective programmes and interventions with adequate monitoring and evaluation. School-based programmes are easily implemented and generally reach a broad group of adolescents, yet out-of-school adolescents remain a particularly vulnerable group ${ }^{(18)}$. Promoting healthy nutrition and obesity prevention is necessary. Promotion measures have been shown to improve knowledge and boost positive attitudes towards healthy diets; however, its effectiveness on behaviour change is mixed ${ }^{(48)}$. Globally, there is growing interest in mobile-based interventions, especially social media, for its potential for a greater reach with less cost; however, to 
our knowledge there is no strong evidence for its effectiveness yet ${ }^{(49)}$. Thus, the type of intervention that fits the Indonesian adolescent profile needs to be explored through qualitative research, with particular attention on youth involvement and empowerment. On a broader view, a life cycle approach may be an ideal approach, which requires a supportive health system ${ }^{(50)}$ and conducive collaboration between policy makers, health service providers and development partners ${ }^{(18,50)}$.

A recent systematic review of the determinants of undernutrition among adolescents in LMIC showed that undernutrition is associated with determinants at the personal level (age, sex, birth order, religion, ethnicity, educational and literacy level, working status and marital status), household level (parental education and occupation, household size and composition, income and socio-economic status) and community level (residence, sanitation, school type and seasonality) $)^{(51)}$. In Indonesia, the challenge is heightened by different social and environmental conditions. Per our findings, all levels of governments in Indonesia should find a way to make everyone realise the critical role that nutrition plays in adolescents' life. It is crucial to provide a thorough information about the urgency of nutrition and health problems of adolescents in Indonesia and why it needs to be intervened immediately. This dissemination of information should be conducted to every layer of the community, not only to adolescents, to be able to provide a supportive environment for adolescents to change their behaviour towards a healthier one. Our review found that many adolescents are skipping breakfast, and unhealthy snacking is still a widespread practice in Indonesian adolescents. We need to change not only the knowledge of these adolescents but also their attitude and behaviour towards a healthier diet. Again, any intervention programmes should aim at adolescents and their social environments. For example, when an adolescent is keen to change their eating pattern to a healthier diet, this cannot be achieved when the parents are not equipped with similar knowledge and ability to provide healthier choices at home. Within this situation, the school also plays a critical role in providing healthier meals and snacks as well as beverages in the school environment.

The next step is building a programme to disseminate information towards Indonesian adolescents and their supportive environments about adolescents' health in general and nutrition education in specific. Nutrition education should include specific knowledge on diet quality and fruit and vegetable consumption, as already highlighted in the 'Isi Piringku' initiatives stated in the Ministry of Health Law no. 41 in $2014^{(52)}$. Considering that the rate of in-school adolescents in Indonesia is high, the school channel is still the most strategic way to intervene. This intervention programme should target adolescents in all areas in Indonesia since living in urban areas did not guarantee that adolescents will have better nutrition knowledge. Our findings highlight that adolescents in urban and peri-urban areas are found to be consuming more energy daily compared with their rural counterparts. Another essential step for the government to take is to consider a way to educate adolescents through a role model for a 'healthier lifestyle'. This role model should be able to convey messages to reduce the consumption of salt and sugar-sweetened beverages, as well as how to support adequate nutrition with physical activity.

Importantly, all currently implemented strategies need to be closely monitored and evaluated for their generalisability, given Indonesia's highly unique and diverse context. Several surveys in Indonesia already collect some dietary indicators, for example, fruit and vegetable consumption and household food consumption from national surveys like the basic health research and national socioeconomic surveys. However, we need to check whether these indicators are in line with the global updates and standards, so they will be comparable to national surveys of other countries. For instance, one could use the global individual food consumption data tool by FAO - WHO as a reference ${ }^{(53)}$. These tools tailor questions for different needs, including health, nutrition and agricultural policy. Adopting such global reference would address the concern on assessment quality issues while ensuring findings are comparable to other countries.

To our knowledge, ours is the first review that gathers extensive evidence of adolescent eating patterns in Indonesia. A strength of the current study is that we performed a systematic literature search of studies in both English and Indonesian languages. The use of a tool to critically appraised studies ensured that only high-quality studies were included in this review. This tool also reduced subjectivity and bias. Lastly, despite the comprehensive search, our findings and conclusion need to be interpreted with acknowledgment of some limitations. First, direct quantitative comparisons between similar studies are not feasible because the different definitions and or measurements of eating pattern variables used by each study. This difference also limited comparisons between age groups where different eating patterns among younger and older adolescents were reported ${ }^{(38)}$. This limitation is also reported by other systematic reviews ${ }^{(38,54,55)}$, with similar reasons, including the paucity of data as well as the confirmed definition or variables in studies among Indonesian adolescents. Second, limited nationwide information limits the ability to generalise findings across Indonesia and to compare subgroups adequately. Third, we acknowledge that since some of the surveys we included in our review were conducted more than 10 years ago, dietary patterns may have changed in the last decade. Lastly, although we realise that food patterns or intake cannot be dissociated from nutritional status, only three out of the included studies depicted nutritional status. Therefore, we were unable to analyse the association between nutritional status and food intake. 
This review also highlights the importance of better definitions and measurement tools for eating patterns in Indonesia, especially for adolescents. Standardised definitions and tools for dietary patterns are essential for all levels of government so that results from the available countrylevel surveys currently in place as well as future surveys can more easily be compared and utilised.

The government should endorse future research that explores the possible differences between sex, age groups (younger, older adolescents) and residents (urban, rural and urban slum). Future studies should also aim to gather evidence using cohort methods, allowing us to monitor trends and changes in eating behaviour among adolescents. Furthermore, a deep understanding of facilitators, barriers and motives of adolescents' food choices will be valuable to inform policymakers on effective interventions. Sustained and evidence-based measures are needed to adequately inform public health policies and programmes in this fourth most populated nation.

\section{Acknowledgements}

Financial support: This work was supported by the Global Alliance for Improved Nutrition (GAIN). Conflict of interest: None stated. Authorship: C.N.R.: formulating the research question(s), designing the analysis, analysing the data and writing the article. H.J.: designing the analysis, analysing the data and writing the article. I.A.: writing the article. T.B.: writing the article. A.S.: formulating the research question(s) and writing the article. Ethics of human subject participation: The current study was conducted according to the guidelines laid down in the Declaration of Helsinki and no ethical clearance was needed.

\section{Supplementary material}

For supplementary material accompanying this paper visit https://doi.org/10.1017/S1368980020002876

\section{References}

1. Craigie AM, Lake AA, Kelly SA et al. (2011) Tracking of obesity-related behaviours from childhood to adulthood: a systematic review. Maturitas 70, 266-284.

2. Delisle H (2005) Nutrition in Adolescence: Issues and Challenges for the Health Sector: Issues in Adolescent Health and Development. Geneva, Switzerland: World Health Organization.

3. Lifshitz F, Tarim O \& Smith M (1993) Nutrition in adolescence. Endocrine Metab Clin North Am 22, 673-683.

4. Black RE, Victora CG, Walker SP et al. (2013) Maternal and child undernutrition and overweight in low-income and middle-income countries. Lancet 382.9890, 427-451.

5. Christian P, Lee S, Donahue-Angel M et al. (2013) Risk of childhood undernutrition related to small-for-gestational age and preterm birth in low- and middle-income countries. Int J Epidemiol 42, 1340-1355.
6. Ahmed F, Zareen M, Khan M et al. (1998) Dietary pattern, nutrient intake and growth of adolescent school girls in urban Bangladesh. Public Health Nutr 1, 83-92.

7. IFPRI (2014) Global Nutrition Report 2014: Actions and Accountability to Accelerate the World's Progress on Nutrition. Washington, DC: International Food Policy Research Institute.

8. Institute IFPR (2015) Global Nutrition Report 2015: Actions and Accountability to Advance Nutrition and Sustainable Development. Washington, DC: International Food Policy Research Institute.

9. Rachmi CN, Agho KE, Li M et al. (2016) Stunting, underweight and overweight in children aged 2.0-4.9 years in Indonesia: prevalence trends and associated risk factors. PLoS One 11, e0154756.

10. Shrimpton R \& Rokx C (2013) The Double Burden of Malnutrition in Indonesia. Jakarta, Indonesia: World Bank Jakarta.

11. Usfar AA, Lebenthal E, Atmarita E et al. (2010) Obesity as a poverty-related emerging nutrition problems: the case of Indonesia. Obes Rev 11, 924-928.

12. Vaezghasemi M, Ohman A, Eriksson M et al. (2014) The effect of gender and social capital on the dual burden of malnutrition: a multilevel study in Indonesia. PLoS One 9, e103849.

13. Badan Penelitian dan Pengembangan Kesehatan KKRI (2014) Status Gizi. In Laporan Hasil Riset Kesehatan Dasar Indonesia tabun 2013, Riskesdas Dalam Angka, pp. 386-415 [DK Indonesia, editor]. Jakarta, Indonesia: CV Kiat Nusa.

14. World Health Organization (2007) WHO Growth Reference for School-aged Children and Adolescents. http://www.who. int/growthref/en/ (accessed March 2015).

15. Ministry of Health Republik Indonesia (2018) Hasil Utama Riskesdas 2018. Jakarta: Ministry of Health Republic of Indonesia.

16. Lipoeto NI, Wattanapenpaiboon N, Malik A et al. (2004) The nutrition transition in West Sumatra, Indonesia. Asia Pac J Clin Nutr 13, 312-316.

17. Indonesia Statistik (2015) Population Projection by Province, 2010-2035. http://www.bps.go.id/linkTabelStatis/view/id/ 1274 (accessed February 2015).

18. Elayn M, Sammon MM, Mehjabeen J et al. (2017) Document Review: Overview of Promising Practices in Adolescent Programming in Indonesia By UNICEF (and Other Partners). Jakarta: Oxford Policy Management Ltd.

19. Rokx C \& Town S (2009) Policy Brief: School Health and Nutrition. Jakarta: World Bank.

20. Sawyer SM, Azzopardi PS, Wickremarathne D et al. (2018) The age of adolescence. Lancet Child Adolesc Health 2, 223-228.

21. Loney PL, Chambers LW, Bennett KJ et al. (1998) Critical appraisal of the health research literature: prevalence or incidence of a health problem. Chronic Dis Can 19, 170-176.

22. Sudiman H \& Jahari AB (2012) Knowledge, attitude and practices of adolescence on nutritional awareness family (Kadarzi): with special attention on body weight monitoring and consuming variety of foods. Media Litbang Kesehatan 22, 93-105.

23. Safitri A, Jahari A \& Ernawati F (2016) Konsumsi Makanan Penduduk Indonesia Ditinjau Dari Norma Gizi Seimbang. Penelitian Gizi dan Makanan (J Nutr Food Res) 39, 87-94.

24. Peltzer K \& Pengpid S (2012) Fruits and vegetables consumption and associated factors among in-school adolescents in five Southeast Asian countries. Int J Environ Res Public Health 9, 3575-3587.

25. Hermina \& Prihatini S (2016) Fruits and vegetables consumption of Indonesian population in the context of balanced nutrition: a further analysis of individual food consumption survey (SKMI) 2014. Buletin Penelitian Kesehatan 44, 205-218.

26. Direktorat Jenderal Bina Kesehatan Masyarakat DKR (2003) Pedoman Umum Gizi Seimbang (PUGS): Panduan Untuk Petugas [DKR Indonesia, editor]. Jakarta, Indonesia: Depkes RI. 
27. Ernawati F \& Saidin M (2008) Determinants of Anemia status among high school students in Jakarta. Penelitian Gizi dan Makanan 31, 82-87.

28. Bahria \& Triyanti (2010) Factors associated with fruits and vegetables consumption among adolescents in SMU 4 in West Jakarta. Jurnal Kesehatan Masyarakat 4, 63-71.

29. Widianto F, Mulyono S \& Fitriyani P (2017) Adolescents can prevent overweight by increasing self-efficacy and vegetable-fruit consumption. IJNP 1, 16-22.

30. Guelinckx I, Iglesia I, Bottin JH et al. (2015) Intake of water and beverages of children and adolescents in 13 countries. Eur J Nutr 54, S69-S79.

31. Prihatini S, Julianti ED \& Hermina (2016) Food contribution in sodium intake of children at young age (6-18 years) in Indonesia. Penelitian Gizi dan Makanan 39, 55-63.

32. Prihatini S, Permaesih D \& Julianti ED (2016) Sodium Intake among Indonesian population: analysis of Individual Food Consumption Survey 2014. J Indonesian Nutr Assoc 39, 15-24.

33. Banowati L \& Nugraheni Puruhita N (2011) Risks of Western fast food consumption and skipping breakfast to adolescents' obesity: a study at SMAN 1 Cirebon. Media Medika Indonesiana 46, 118-124.

34. Lentini B \& Margawati A (2014) Relationship of breakfast habits and hydration status with concentration of thinking in adolescents. J Nutr Coll 3, 631-637.

35. Niswah I, Damanik MR \& Ekawidyani KR (2014) Breakfast habits, nutritional status, and health related quality of life of adolescents in Bosowa Bina Insani junior high school Bogor. J Gizi dan Pangan 9, 97-102.

36. Agusanty SF, Kandarina I \& Gunawan IMA (2014) Breakfast and snacking as risk factors of overweight in senior high school. J Gizi Klinik Indonesia 10, 139-149.

37. Hidayanty H, Bardosono S, Khusun H et al. (2016) A social cognitive theory-based programme for eating patterns and sedentary activity among overweight adolescents in Makassar, South Sulawesi: a cluster randomised controlled trial. Asia Pac J Clin Nutr 25, S83-S92.

38. Keats EC, Rappaport AI, Jain R et al. (2018) Diet and Eating Practices Among Adolescent Girls in Low- and MiddleIncome Countries: A Systematic Review. Arlington, VA: Strengthening Partnerships, Results, and Innovations in Nutrition Globally (SPRING) project.

39. Baker P \& Friel S (2014) Processed foods and the nutrition transition: evidence from Asia. Obes Rev 15, 564-577.

40. Usfar AA \& Fahmida U (2011) Do Indonesians follow its dietary guidelines? Evidence related to food consumption, healthy lifestyle, and nutritional status within the period 2000-2010. Asia Pac J Clin Nutr 20, 484-494.

41. Havas S, Dickinson BD \& Wilson M (2007) The urgent need to reduce sodium consumption. JAMA 298, 1439-1441.
42. Mozaffarian D, Fahimi S, Singh GM et al. (2014) Global sodium consumption and death from cardiovascular causes. NE J Med 371, 624-634.

43. Atun L, Siswati T \& Kurdanti W (2014) Asupan Sumber Natrium, Rasio Kalium Natrium, Aktivitas Fisik, Dan Tekanan Darah Pasien Hipertensi. Media Gizi Mikro Indonesia 6, 63-71.

44. Rahajeng E, Kristanti D \& Kusumawardani N (2016) Perbedaan laju kecepatan terjadinya hipertensi menurut konsumsi natrium [studi kohort prospektif di Kota Bogor, Jawa Barat, Indonesia] (The incidence rate difference of hypertension according to sodium consumption [A prospective cohort study in Bogor city, West Java, Indonesia]). Penelitian Gizi dan Makanan (J Nutr Food Res) 39, 45-53.

45. Meneely GR \& Battarbee HD (1976) High sodium-low potassium environment and hypertension. Am J Cardiol 38, 768-785.

46. Chika H, Satoru K, Yoko Y et al. (2011) Skipping breakfast and prevalence of overweight and obesity in Asian and Pacific regions: a meta-analysis. Preven Med 53, 260-267.

47. Gayle Savige AM, Kylie B, Anthony W et al. (2007) Snacking behaviours of adolescents and their association with skipping meals. Int J Behav Nutr Phys Act 4, 36.

48. Salam RAMS, Hooda MMD, Das JKMDMBA et al. (2016) Interventions to improve adolescent nutrition: a systematic review and meta-analysis. J Adolesc Health 59, S29-S39.

49. Williams G, Hamm MP, Shulhan J et al. (2014) Social media interventions for diet and exercise behaviours: a systematic review and meta-analysis of randomised controlled trials. BMJ Open 4, e003926.

50. Branca F, Piwoz E, Schultink W et al. (2015) Nutrition and health in women, children, and adolescent girls. $\mathrm{Br}$ Med J 351, h4173.

51. Madjdian DS, Azupogo F, Osendarp SJM et al. (2018) Sociocultural and economic determinants and consequences of adolescent undernutrition and micronutrient deficiencies in LLMICs: a systematic narrative review. Ann NY Acad Sci 1416, 117-139.

52. Ministry of Health Republik Indonesia (2014) Isi Piringku. http://www.kesmas.kemkes.go.id/assets/upload/dir_ 519d41d8cd98f00/files/LEAFLET-ISI-PIRINGKU-ilovepdfcompressed_1011.pdf (accessed April 2019).

53. Leclercq C, Allemand P, Balcerzak A et al. (2019) FAO/WHO GIFT (Global Individual Food consumption data Tool): a global repository for harmonised individual quantitative food consumption studies. Proc Nutr Soc 78, 484-495.

54. Pearson N, Biddle SJ \& Gorely T (2008) Family correlates of fruits and vegetable consumption in children and adolescents: a systematic review. Public Health Nutr 12, 267-283.

55. Pearson N, Biddle SJH \& Gorely T (2009) Family correlates of breakfast consumption among children and adolescents: a systematic review. Appetite 52, 1-7. 